\title{
PENGARUH DOSIS RAGI DAN PENAMBAHAN GULA TERHADAP KUALITAS GIZI DAN ORGANOLEPTIK TAPE BIJI GANDUM
}

\section{THE EFFECT OF YEAST DOSAGE AND SUGAR ADDITION ON THE QUALITY OF GRAIN WHEAT TAPE}

\author{
${ }^{1}$ Jalalina Abdillah ${ }^{2}$ Nugraheni Widyawati ${ }^{2}$ Suprihati
}

Diterima 14 Maret 2014, disetujui 28 Mei 2014

\begin{abstract}
Tape yeast in certain dose is required in making tape. Addition of 5\% sugar could increase the sweetness as well as energy for the microorganissm. The experiment about the effect of yeast dosage and sugar addition on the quality of wheat grain tape in the Laboratory of Faculty of Science and Mathematics Satya Wacana Christian University started from $29^{\text {th }}$ February until $23^{\text {rd }}$ April 2012. This research used Randomized Block Design (RBD) with six treatments as follows: $1 \%$ yeast; $2 \%$ yeast; $3 \%$ yeast; $1 \%$ yeast with sugar; $2 \%$ yeast with sugar; $3 \%$ yeast with sugar. Finally, data of the result were analyzed using analysis of variance (ANOVA) and honestly significant difference (HSD) at 5\% level. The research showed that: 1) 1\% yeast dose had the highest quality of wheat tape compared to $2 \%$ and $3 \%$ yeast dose, 2) $1 \%$ yeast dose with sugar gave the best taste from organoleptic test.
\end{abstract}

Keyword: addition sugar, tape, wheat, yeast dose

\section{PENDAHULUAN}

Tape merupakan hasil dari proses fermentasi bahan-bahan yang mengandung karbohidrat seperti beras ketan. Fermentasi adalah salah satu reaksi oksidasi reduksi dalam sistem biologi yang menghasilkan energi (Winarno dan Fardiaz, 1984). Mikroorganisme yang dibutuhkan pada umumnya terdapat dalam ragi dan efektifitas penggunaan ragi ditentukan oleh takaran antara ragi dengan bahan pangan yang akan difermentasi. Dalam membuatan tape, hal penting yang perlu diperhatikan adalah takaran ragi dengan bahan dasar yang digunakan. Ragi yang ditambahkan biasanya kurang dari $10 \mathrm{~g}$ per $\mathrm{kg}$ bahan (Hidayat, 2006).

Sejauh ini biji gandum yang diproduksi di dalam negeri ditujukan untuk memenuhi kebutuhan konsumsi dalam negeri dan menurunkan ketergantungan terhadap impor gandum. Gandum impor yang dikenal masyarakat pada umumnya berbentuk tepung yang disebut terigu. Sementara gandum yang diproduksi di dalam negeri berbentuk biji gandum. Masyarakat Indonesia belum banyak mengenal pengolahan gandum dalam bentuk biji. Oleh karena itu diperlukan eksplorasi dan sosialisasi dalam pengolahan biji gandum. Salah satu kemungkinan cara pengolahannya dapat dibuat menjadi tape seperti pada tape beras ketan.

Kelebihan biji gandum jika dibanding beras ketan adalah pada kandungan proteinnya, dimana protein biji gandum lebih tinggi dibandingkan beras ketan. Biji Gandum varietas Dewata yang di produksi Fakultas Pertanian dan Bisnis Universitas Kristen Satya Wacana (UKSW)

\footnotetext{
${ }^{1}$ Alumni Fakultas Pertanian dan Bisnis Universitas Kristen Satya Wacana, email: abdillahjalalina24@ gmail.com ${ }^{2}$ Dosen Fakultas Pertanian dan Bisnis Universitas Kristen Satya Wacana, Salatiga. email: heniwidya@ gmail.com
} 
mengandung 67,44 persen karbohidrat dan 11,63 persen protein (Murtini dkk, 2005). Namun sejauh ini belum ada penelitian tape biji gandum.

Pembuatan tape dengan takaran ragi terlalu sedikit mengakibatkan proses fermentasi menjadi lambat, sebaliknya jika takaran ragi terlalu banyak maka proses fermentasi dan pembusukan yang terjadi terlalu cepat dan kurang efektif. Sehingga perlu adanya penelitian tentang takaran ragi yang tepat pada pembuatan tape biji gandum.

Cita rasa tape yang disukai oleh masyarakat sangat ditentukan oleh rasa manisnya. Untuk meningkatkan rasa manis dapat dilakukan dengan penambahan gula. Gula tersebut juga dapat berfungsi sebagai stater mikroorganisme untuk mempercepat proses fermentasi. Semakin manis rasa pada tape umumnya tingkat penerimaan terhadap tape semakin tinggi. Dalam hal ini perlu diadakan penelitian tentang perlu tidaknya penambahan gula pada pembuatan tape biji gandum.

\section{METODE PENELITIAN}

\section{a. Lokasi dan waktu penelitian}

Penelitian dilaksanakan di Laboratorium Fakultas Sains dan Matematika UKSW Salatiga, provinsi Jawa Tengah. Penelitian dilaksanakan pada tanggal 29 Februari 2012 sampai dengan 23 April 2012.

\section{b. Rancangan percobaan}

Penelitian ini menggunakan Rancangan Acak Kelompok (RAK) dengan enam perlakuan yaitu:

\begin{tabular}{l|l}
\hline $\mathrm{P} 1$ & $\begin{array}{l}10 \mathrm{~g} \text { ragi } / 1000 \mathrm{~g} \text { biji gandum, } \\
\text { tanpa penambahan gula }\end{array}$ \\
\hline $\mathrm{P} 2$ & $\begin{array}{l}\text { 20 g ragi } / 1000 \mathrm{~g} \text { biji gandum, } \\
\text { tanpa penambahan gula }\end{array}$ \\
\hline $\mathrm{P} 3$ & $\begin{array}{l}\text { 30 g ragi/ } 1000 \mathrm{~g} \text { biji gandum, } \\
\text { tanpa penambahan gula }\end{array}$ \\
\hline $\mathrm{P} 4$ & $\begin{array}{l}10 \mathrm{~g} \text { ragi } / 1000 \mathrm{~g} \text { biji gandum dan } 50 \mathrm{~g} \text { gula } / 1000 \mathrm{~g} \\
\text { biji gandum }\end{array}$ \\
\hline $\mathrm{P} 5$ & $\begin{array}{l}\text { 20 g ragi } / 1000 \mathrm{~g} \text { biji gandum dan } 50 \mathrm{~g} \text { gula } / 1000 \mathrm{~g} \\
\text { biji gandum }\end{array}$ \\
\hline $\mathrm{P} 6$ & $\begin{array}{l}\text { 30 g ragi } / 1000 \mathrm{~g} \text { biji gandum dan } 50 \mathrm{~g} \text { gula } / 1000 \mathrm{~g} \\
\text { biji gandum }\end{array}$ \\
\hline
\end{tabular}

\section{c. Tahapan Penelitian}

Tahapan penelitian ini terdiri atas dua kegiatan percobaan yaitu: (1) pembuatan tape biji gandum (2) uji gizi dan organoleptik tape biji gandum.

\section{(1) Pembuatan Tape Biji Gandum}

Bahan yang digunakan dalam penelitian ini adalah biji gandum utuh varietas Dewata produksi Fakultas Pertanian dan Bisnis Universitas Kris-ten Satya Wacana. Sebelum digunakan, ragi ditumbuk halus dan diayak terlebih dahulu agar memberikan ukuran yang sama pada setiap perlakuan. Perebusan dilakukan dua kali, masing-masing selama 30 menit. Fermentasi dilakukan secara anaerobik. Selama inkubasi berlangsung tempat bahan yang difermentasi dimasukkan ke dalam kantong plastik hitam agar terhindar dari cahaya yang masuk yang dimungkinkan dapat memicu pertumbuhan organisme lain yang tidak diinginkan.

\section{(2) Uji Gizi dan Organoleptik Tape Biji Gandum}

Parameter yang diamati dan diukur kandungan gizi dan Organoleptik. Pengukuran kandungan gizi meliputi: (1) Kandungan gula pereduksi diukur dengan Spektrofotometer menggunakan reagen Dinitrosalicylic acid (2) Kandungan protein diukur dengan metode Biuret (3) Kandungan Alkohol menggunakan metode Iodometri (4) Kandungan air dengan metode Gravimetri. Pengukuran kesukaan organoleptik meliputi: (1) Nilai kesukaan rasa (2) Nilai kesukaan aroma (3) nilai kesukaan tekstur (4) nilai kesukaan keseluruhan, yang keempatnya menggunakan metode Afeksi berdasarkan tingkat kesukaan yang melibatkan 36 panelis. Untuk parameter suhu ruangan diamati setiap hari, sedangkan parameter kandungan air, protein, gula pereduksi, alkohol, nilai kesukaan rasa, aroma, tektur dan keseluruhan diukur pada hari ke-3 dan 5 setelah inkubasi.

\section{PEMBAHASAN}

\section{Suhu}

Dari hasil pengamatan suhu udara, rata-rata suhu udara minimum $25,70^{\circ} \mathrm{C}$ dan maksimum $26,77^{\circ} \mathrm{C}$ 
selama proses fermentasi. Menurut Fardiaz (1992) suhu pertumbuhan untuk khamir adalah sama dengan suhu optimum pada kapang sekitar (25$30)^{\circ} \mathrm{C}$ dan suhu maksimum kira-kira $(35-47)^{\circ} \mathrm{C}$, yang artinya suhu di dalam penelitian ini khamir yang diberikan tumbuh baik pada suhu optimum.

\section{Kandungan Air}

Penambahan gula cenderung meningkatkan kandungan air baik pada hari ke-3 atau ke-5. Fermentasi adalah proses produksi energi dalam sel dalam keadaan anaerobik maupun aerobik. Fermentasi ini melibatkan mikroorganisme Saccharomyces cereviceae, Saccharomyces bersifat fermentatif kuat. Namun, dengan adanya oksigen, Saccharomyces cereviceae juga dapat melakukan respirasi yaitu mengoksidasi gula menjadi karbondioksida dan air yang keduanya terjadi di jalur glikolisis.

Peningkatan dosis ragi dari 1 persen sampai 3 persen memperlihatkan kandungan air yang tidak berbeda nyata pada perlakuan tanpa gula ataupun dengan gula, baik pada hari ke-3 atau ke-5. Kandungan air dipengaruhi oleh banyak sedikitnya gula, selain gula yang akan di pecah menjadi air, energi dan karbondioksida dalam jalur glikolisis aerob karena masih tersedianya oksigen.

Penambahan gula yang sama dengan dosis ragi yang berbeda-beda menunjukkan kandungan air yang tidak berbeda (Tabel 1.). Menurut Hidayat (2006), faktor pertumbuhan mikroba salah satunya adalah kompetisi, hal ini terjadi karena adanya kebutuhan nutrisi yang sama dalam satu ruang lingkup. Hasil dari aktivitas mikroba disini adalah pemecahan gula menjadi karbondioksida dan air.

Penambahan lama fermentasi memiliki kecenderungan menurunkan kandungan air tape gandum baik pada penambahan gula atau tanpa gula, semakin lama fermentasi maka kandungan oksigen berkurang karena diduga sudah digunakan Saccaromyces cereviceae untuk respirasi dan menghasilkan energi, karbondioksida dan air.

\section{Kandungan Protein}

Penambahan gula tidak memperlihatkan adanya perbedaan nyata terhadap kandungan protein baik pada hari ke-3 maupun hari ke-5. Mikro-organisme menggunakan gula yang ditambahkan. Gula halus termasuk dalam sukrosa, sukrosa ter-bentuk dari monomer glukosa dan fruktosa. Glukosa adalah

Tabel 1. Pengaruh Dosis Ragi dan Penambahan Gula terhadap Kandungan Air Tape Biji Gandum Pada Pengamatan Hari ke-3 dan ke-5

\begin{tabular}{|c|c|c|c|}
\hline \multirow{2}{*}{ Perlakuan } & \multicolumn{3}{|c|}{ Kandungan Air \% (w/w) } \\
\hline & Hari ke -3 & Hari & $\mathrm{ke}-5$ \\
\hline Ragi $1 \%$ & $27,002 \mathrm{ab}$ & 24,018 & A \\
\hline Ragi 2\% & $26,758 \quad a b$ & 25,672 & $\mathrm{Ab}$ \\
\hline Ragi 3\% & 25,855 a & 25,433 & $\mathrm{Ab}$ \\
\hline Ragi $1 \%+$ gula & $29,608 \quad b$ & 28,812 & B \\
\hline Ragi $2 \%$ +gula & $29,315 \quad b$ & 27,704 & B \\
\hline Ragi 3\% +gula & $29,512 \quad b$ & 28,196 & B \\
\hline
\end{tabular}

Keterangan : Nilai KV hari ke-3 =3,09\%; KV Hari ke-5 =3,37\%. Angka yang memiliki huruf yang sama menunjukan tidak adanya perbedaan nyata antar perlakuan menurut uji BNJ pada taraf 5\%. Sebaliknya apabila angka yang diikuti huruf yang berbeda menunjukan adanya perbedaan yang nyata antar perlakuan menurut uji BNJ pada taraf 5\%. 
gula paling sederhana dalam menghasilkan energi. Pada semua perlakuan terjadi pemanfaatan karbohidrat diubah menjadi gula sederhana dan diubah menjadi energi oleh mikroorganisme Saccaromyces cereviceae. Hal ini di dukung oleh teori Desrosier (1988) bahwa mikroba pada fermentasi membutuhkan karbohidrat, protein, lemak, mineral, dan bahan lain, namun mikroba mendahulukan karbohidrat yang paling sederhana berupa gula.

Penambahan gula memiliki kecenderungan meningkatkan kandungan protein pada hari ke-3. Gula yang di tambahkan memacu lebih cepat pertumbuhan mikroba untuk menghasilkan enzim-enzim yang dihasilkan oleh Saccaromyces cereviceae, enzim merupakan bentuk dari protein. Saccaromyces cereviceae mampu mensekresikan beberapa enzim ektraselular (protein) selama proses fermentasi [Akindahusni et al, (1999) dan Okafor (1998) dalam Dewi (2009)]. Menurut penelitian Isnariani (1993, lihat Septiani dkk, 2004), enzim yang terdapat pada kapang adalah amilase, invertase, dan protease. Menurut Rahayu dkk, (1993, lihat dalam Septiani dkk,
2004), pati dihidrolisis menjadi disakarida dan monosakarida oleh amilase dan invertase. Selama proses fermentasi terjadi kenaikan nitrogen terlarut, asam amino, amonia, nilai $\mathrm{pH}$, dan suhu. Pada pengamatan hari ke-5 penambahan gula memiliki kecenderungan menurunkan kandungan protein tape. Hal tersebut disebabkan nutrisi pada substrat yang berupa protein mulai digunakan oleh mikroba dikarenakan gula yang ditambahkan mampu mempercepat pertumbuhan mikroba sehingga mengakibatkan keterbatasan nutrisi dalam bentuk gula dan lemak.

Pada Tabel 2 menunjukkan dosis ragi tidak memberikan perbedaan nyata terhadap kandungan protein yang dihasilkan.

Dosis ragi mulai dari 1 persen telah terjadi keseimbangan antara nutrisi dalam substrat dan jumlah mikroba, dan kandungan protein pada perlakuan dosis ragi baik dengan atau tanpa gula dan baik hari ke-3 atau ke-5 cenderung sama. Hal ini juga sesuai dengan penelitian Anindita (2007) yang menyatakan bahwa kandungan protein pada semua perlakuan dosis inokulum hampir sama.

Tabel 2. Pengaruh Dosis Ragi dan Penambahan Gula terhadap Kandungan Protein Tape Gandum pada Periode Pengamatan Hari ke - 3 dan ke - 5

\begin{tabular}{ccccc}
\hline \multirow{2}{*}{ Perlakuan } & \multicolumn{4}{c}{ Kandungan Protein $\%(w / w)$} \\
\cline { 2 - 5 } Hari ke - 3 & \multicolumn{2}{c}{ Hari ke - 5 } \\
\hline Ragi 1\% & 0,170 & a & 0,188 & a \\
Ragi 3\% & 0,147 & a & 0,181 & a \\
Ragi 1\% + gula & 0,153 & a & 0,166 & a \\
Ragi 2\% +gula & 0,185 & a & 0,176 & a \\
Ragi 3\% +gula & 0,169 & a & 0,163 & a \\
\hline
\end{tabular}

Keterangan : Nilai KV hari ke-3=7,22\%; KV hari ke-5 = 8,40\%. Angka yang memiliki huruf yang sama menunjukkan tidak adanya perbedaan nyata antar perlakuan menurut uji BNJ pada taraf $5 \%$. Sebaliknya apabila angka yang diikuti huruf yang berbeda akan menunjukkan adanya perbedaan yang nyata antar perlakuan menurut uji BNJ pada taraf $5 \%$. 


\section{Kandungan Gula Pereduksi}

Penambahan gula memberikan perbedaan nyata terhadap kandungan gula pereduksi pada hari ke-3, namun tidak memberikan perbedaan nyata pada hari ke-5. Kandungan gula pereduksi paling tinggi pada dosis ragi 1 persen dengan gula, meskipun hasilnya tidak berbeda nyata dengan dosis ragi 1 persen tanpa gula (huruf) baik pada hari ke-3 dan ke-5. Perbedaan kandungan gula pereduksi pada hari ke-3 terkait dengan proses hidrolisis pati menjadi gula dan pemanfaatan gula menjadi energi oleh kapang. Pada perlakuan tanpa gula pada hari ke-3 menghasilkan kandungan gula pereduksi yang tidak berbeda nyata, hal tersebut disebabkan kandungan nutrisi (pati) pada substrat pada ketiga dosis ragi adalah sama. Hal inilah yang menyebabkan kandungan gula pereduksinya sama. Banyaknya gula yang dihasilkan dalam hidrolisis pati/karbohidrat dipengaruhi oleh banyaknya pati/karbohidrat itu sendiri. Semakin banyak pati/karbohidrat yang terkandung pada suatu bahan maka semakin tinggi kandungan gula pereduksi. Hal ini didukung teori Desrosier (1988) kebutuhan utama dari mikroorganisme adalah sumber energi, karbohidrat yang terlarut dan cepat tersedia berpengaruh pada populasi dan aktivitas mikroba.
Dosis ragi 1 persen dengan gula menghasilkan kandungan gula pereduksi paling tinggi jika dibandingkan dengan perlakuan lain bila dilihat dari nilai yang dihasilkan. Hal tersebut diduga karena jumlah mikroorganisme yang sedikit sehingga perombakan gula menjadi energipun juga rendah. Berbeda dengan perlakuan ragi 2 persen dan 3 persen dengan gula, disini jumlah gula yang di berikan sama namun jumlah ragi yang diberikan lebih banyak sehingga diduga terjadi pemanfaatan gula oleh mikroorganisme lebih banyak jika dibandingkan dengan perlakuan ragi 1 persen dengan gula.

Semakin tinggi pemberian dosis ragi maka cenderung menurunkan kandungan gula reduksi yang dihasilkan baik pada perlakuan tanpa gula atau dengan ditambah gula, hal tersebut di kuatkan oleh penelitian Simbolon (2008), jumlah mikroba perombak yang terdapat di dalam tape lebih banyak, terutama enzim invertase yang dihasilkan semakin banyak, sehingga semakin banyak glukosa yang dirombak menjadi etanol dan akibatnya kandungan gula reduksi menurun.

Penambahan hari memiliki potensi cenderung menurunkan kandungan gula pereduksi tape. Menurut Simbolon (2008), semakin lama waktu fermentasi, maka kandungan gula reduksi

Tabel 3. Pengaruh Dosis Ragi dan Penambahan Gula Terhadap Kandungan Gula Pereduksi Tape Gandum pada Periode Pengamatan Hari ke - 3 dan ke - 5

\begin{tabular}{ccccc}
\hline \multirow{2}{*}{ Perlakuan } & \multicolumn{3}{c}{ Kandungan Gula Pereduksi \% (w/w) } \\
\cline { 2 - 5 } & \multicolumn{2}{c}{ Hari ke -3} & \multicolumn{2}{c}{ Hari ke - 5 } \\
\hline Ragi 1\% & 13,859 & $\mathrm{~b}$ & 9,830 & $\mathrm{~A}$ \\
Ragi 2\% & 12,903 & ab & 9,598 & $\mathrm{~A}$ \\
Ragi 3\% & 12,752 & ab & 8,548 & $\mathrm{~A}$ \\
Ragi 1\% + gula & 14,885 & $\mathrm{~b}$ & 11,414 & $\mathrm{~A}$ \\
Ragi 2\% + gula & 10,478 & ab & 9,449 & $\mathrm{~A}$ \\
Ragi 3\% + gula & 10,269 & $\mathrm{a}$ & 9,517 & $\mathrm{~A}$ \\
\hline
\end{tabular}

Keterangan : Nilai KV hari ke-3 $=7,73 \%$; KV hari ke- $5=10,73 \%$. Angka yang memiliki huruf yang sama menunjukkan tidak adanya perbedaan nyata antar perlakuan menurut uji BNJ pada taraf $5 \%$. Sebaliknya apabila angka yang diikuti huruf yang berbeda akan menunjukan adanya perbedaan yang nyata antar perlakuan menurut uji BNJ pada taraf $5 \%$. 
menurun, karena semakin banyak glukosa yang dirombak menjadi alkohol, sehingga kandungan alkohol yang dihasilkan semakin tinggi dan gula reduksi yang dihasilkan semakin menurun.

\section{Kandungan Alkohol}

Dosis ragi dan penambahan gula tidak memperlihatkan adanya perbedaan nyata Mulai dengan dosis ragi 1 persen telah terjadi keseimbangan antara ketersediaan sumber nutrisi dalam medium dan jumlah mikroba, dan selanjutnya sampai akhir fermentasi peningkatan jumlah mikroba pada semua perlakuan dosis ragi cenderung statis. Peranan mikroorganisme di dalam fermentasi di bagi menjadi dua berdasarkan tahap fermentasi kapang (Clamydomисо oryzae) mengubah pati menjadi gula sederhana dankhamir (Saccaromycopsis sp. 1; Saccaromyces sp.) yang mengubah gula menjadi alkohol dan senyawa lain. Dalam keadaan anaerobik, khamir lebih cenderung memfermentasi karbohidrat untuk menghasilkan alkohol.

Dalam jalur glikolisis etanol yang sudah dihasilkan diubah menjadi ester, asam asetat dan keton sebagai sumber aroma tape. Hal ini sesuai dengan reaksi jalur glikolisis seperti yang dijelaskan sebelumnya [Anonim ${ }^{\mathrm{b}}$ (2006); (Anindita (2007)].

\section{Kesukaan Rasa, Tekstur, Aroma dan Keseluruhan}

Dosis ragi 1 persen dengan gula pada pengamatan hari ke-3 cenderung menghasilkan nilai kesukaan rasa tertinggi meskipun tidak berbeda nyata dengan perlakuan dosis ragi 1 persen tanpa gula pada hari yang sama. Dalam proses fermentasi terjadi reaksi antara air dengan pati yang disebut dengan hidrolisis. Proses hidrolisis ini sangat lambat sehingga membutuhkan katalisator berupa enzim yang dihasilkan oleh mikroorganisme yang digunakan. Menurut Judoamidjojo (1990, lihat dalam Asngad 2009), $S$. cereviceae mempunyai daya konversi gula yang sangat tinggi karena menghasilkan enzim zimase dan invertase, yang kita tahu enzim zimase berfungsi sebagai pemecah sukrosa menjadi monosakarida (glukosa dan fruktosa).

Menurut Rubatzky dan Yamaguchi (1988), pada proses fermentasi akan terjadi perombakan karbohidrat menjadi glukosa dan fruktosa, serta senyawa lainya. Diduga pada dosis ragi 1 persen dengan gula khamir Saccaromyces cereviceae

Tabel 4. Pengaruh Dosis Ragi dan Penambahan Gula Terhadap Kandungan Alkohol Tape Gandum pada Periode Pengamatan Hari ke-3 dan ke-5

\begin{tabular}{cllll}
\hline Perlakuan & \multicolumn{4}{c}{ Kandungan alkohol \% $(\mathrm{w} / \mathrm{w})$} \\
\cline { 2 - 5 } Ragi 1\% & 0,394 & $\mathrm{a}$ & 0,430 & $\mathrm{a}$ \\
Ragi $2 \%$ & 0,410 & $\mathrm{a}$ & 0,433 & $\mathrm{a}$ \\
Ragi 3\% & 0,413 & $\mathrm{a}$ & 0,426 & $\mathrm{a}$ \\
Ragi 1\% + gula & 0,412 & $\mathrm{a}$ & 0,457 & $\mathrm{a}$ \\
Ragi 2\% + gula & 0,405 & $\mathrm{a}$ & 0,434 & $\mathrm{a}$ \\
Ragi 3\% + gula & 0,400 & a & 0,440 & $\mathrm{a}$ \\
\hline
\end{tabular}

Keterangan : Nilai KV hari ke-3=1,79\%; KV hari ke-5=2,43\% . Angka yang memiliki huruf yang sama menunjukan tidak adanya perbedaan nyata antar perlakuan menurut uji BNJ pada taraf 5\%. Sebaliknya apabila angka yang diikuti huruf yang berbeda akan menunjukan adanya perbedaan yang nyata antar perlakuan menurut uji BNJ pada taraf $5 \%$. 
merombak karbohidrat pada gandum dan perlakuan penambahan gula yang diberikan mampu meningkatkan rasa manis pada tape sehingga dalam hasil analisis menunjukkan penambahan gula dengan dosis ragi 1 persen menghasilkan kesukaan rasa tertinggi. Perlakuan dosisi ragi 1 persen tanpa gula dan dengan gula menghasilkan perbedaan yang tidak nyata. Hal ini diduga pada saat yang sama gula yang ditambahkan diubah oleh enzim invertase yang dihasilkan oleh $S$. cereviceae yang kita tahu peran dari enzim ini adalah mengubah glukosa menjadi etanol. Dalam penelitian ini dapat dilihat, semakin tinggi dosis ragi maka semakin menurunkan nilai kesukaan rasa tape. Organoleptik rasa erat kaitannya dengan kemanisan yang cukup tinggi dengan kadar alkohol rendah serta kadar asam yang tinggi. Hal ini di dukung oleh Buckle, et al., (1987) dan penelitian Simbolon (2009), yang menyatakan bakteri asam asetat seperti Acetobacter aceti melakukan metabolisme yang bersifat aerobik. Peranan utamanya dalam fermentasi bahan pangan adalah mengoksidasi alkohol dan karbohidrat lainya menjadi asam asetat. Asam yang dihasilkan dengan cara tersebut akan menurunkan $\mathrm{pH}$ lingkungan pertumbuhanya dan menimbulkan rasa asam. Jika tumbuh dalam keadaan anaerobik, kebanyakan khamir lebih cenderung memfermentasi karbohidat untuk menghasilkan etanol dan sedikit produk akhir lainya. Jika presentase ragi tape semakin tinggi, kadar alkohol dan keasaman tape gandum akan semakin meningkat, kadar gula menurun, sehingga organoleptik rasa menurun.

Penambahan gula mampu meningkatkan kesukaan rasa tape baik pada hari ke-3 maupun ke-5. Dalam proses fermentasi terjadi reaksi antara air dengan pati yang disebut dengan hidrolisis. Proses hidrolisis ini sangat lambat sehingga membutuhkan katalisator berupa enzim. Dalam penelitian ini enzim yang digunakan adalah enzim yang dihasilkan oleh mikroorganisme yang digunakan. Menurut Judoamidjojo (1990, dalam Asngad 2009), S. cereviceae mempunyai daya konversi gula yang sangat tinggi karena meng- hasilkan enzim zimase dan invertase, yang kita tahu enzim zimase berfungsi sebagai pemecah sukrosa menjadi monosakarida (glukosa dan fruktosa). Seperti yang sudah dijelaskan oleh Rubatzky dan Yamaguchi (1988) sebelumnya, pada perlakuan penambahan gula terjadi perombakan pati menjadi glukosa yang menimbulkan rasa manis ditambah dengan penambahan gula untuk meningkatkan rasa manis, tidak heran jika pada perlakuan penambahan gula menghasilkan kesukaan rasa lebih tinggi jika dibandingkan perlakuan tanpa gula.

Penambahan hari memiliki potensi cenderung menurunkan nilai kesukaan rasa tape gandum. Semakin lama fermentasi maka nilai kesukaan rasa tape yang dihasilkan maka semakin menurun. Hal ini disebabkan dengan semakin lamanya fermentasi, produksi asam semakin tinggi di dalam tape yang dihasilkan sehingga membuat tape semakin asam. Peranan utama bakteri asam asetat seperti Acetobacter aceti dalam fermentasi bahan pangan adalah mengoksidasi alkohol dan karbohidrat lainya menjadi asam asetat. Asam yang dihasilkan dengan cara tersebut akan menurunkan nilai $\mathrm{pH}$ lingkungan pertumbuhanya dan menimbulkan rasa asam. Asam yang dihasilkan pada proses fermentasi diantaranya asam laktat, asam asetat, asam formiat, asam butirat dan asam propionate. Asam-asam tersebut dihasilkan dari perombakan glukosa dan alkohol. Setelah glukosa dan alkohol dihasilkan barulah diperoleh asam [Buckle et al., (1987); Amerine et al., (1972); Desrosier (1988)]. Menurut Fardiaz dkk. (1996), produksi alkohol yang berlebihan dapat menimbulkan rasa pahit, sebaliknya produksi alkohol minimal meningkatkan rasa manis tape.

Perbedaan dosis ragi yang diberikan tidak memperlihatkan nilai kesukaan tekstur nyata baik pada perlakuan dengan gula atau tanpa gula. Semakin besar persentase ragi tape maka nilai kesukaan tekstur yang dihasilkan semakin menurun. Hal ini dikarenakan pati telah dirombak oleh mikro- 
organisme perombak menjadi bentuk cair (air, asam-asam organik) dan berbentuk gas (alkohol). Menurut Hidayat, et al., (2006) fermentasi dapat merupakan sebagai perubahan gradual oleh enzim beberapa bakteri, khamir dan jamur. Pada pengamatan hari ke-3 Tabel 5, dapat dilihat bahwa kesukaan tekstur tertinggi pada perlakuan dosis 1 persen dan 2 persen yang masing-masing dengan penambahan gula. Penulis lebih menyukai tekstur yang agak keras namun manis pada tape gandum yang berkebalikan dengan kesukaan tape singkong pada umumnya.

Penambahan gula cenderung meningkatkan nilai kesukaan tekstur tape baik pada hari ke-3 maupun hari ke-5. Namun jika dilihat lebih jelas, semakin tinggi dosis ragi tidak meningkatkan kesukaan tekstur tape, penggunaan ragi 1 persen dengan gula menghasilkan nilai kesukaan tekstur cenderung tertinggi meskipun hasilnya tidak berbeda dengan perlakuan dosis ragi 1 persen tanpa gula. Menurut Setyohadi (2006), semakin tinggi persentase ragi tape, semakin banyak khamir (Saccaromyces cereviceae) dan bakteri (Acetobacter aceti) yang menyebabkan tape semakin lunak, namun tekstur lunak pada kesukaan tape gandum tidak begitu diminati oleh panelis. Berbeda dengan kesukaan yang diinginkan panelis pada tape singkong pada umumnya yang menginginkan tekstur berair, dalam selera tekstur tape gandum ini panelis lebih menginginkan tekstur tape masih

Tabel 5. Pengaruh Dosis Ragi dan Penambahan Gula Terhadap Nilai Kesukaan Rasa, Tekstur, Aroma dan Keseluruhan Tape Gandum pada Periode Pengamatan Hari ke-3 dan ke-5

\begin{tabular}{|c|c|c|c|c|c|c|c|c|}
\hline \multirow[t]{2}{*}{ Perlakuan } & \multicolumn{4}{|c|}{ Nilai Kesukaan Hari ke - 3} & \multicolumn{4}{|c|}{ Nilai Kesukaan Hari ke - 5} \\
\hline & Rs & $\mathrm{Tkr}$ & Arm & Kslrn & Rs & $\mathrm{Tkr}$ & Arm & Kslrn \\
\hline \multirow{2}{*}{ Ragi $1 \%$} & 2,889 & 2,917 & 3,278 & 3,000 & 2,306 & 2,778 & 3,139 & 2,639 \\
\hline & $a b$ & $\mathrm{ab}$ & $\mathrm{a}$ & $\mathrm{ab}$ & $\mathrm{ab}$ & $\mathrm{a}$ & $a b$ & $\mathrm{ab}$ \\
\hline \multirow{2}{*}{ Ragi 2\% } & 2,500 & & 3,056 & 2,639 & 2,361 & 2,889 & 3,000 & 2,472 \\
\hline & $\mathrm{a}$ & $2,944 \mathrm{ab}$ & $\mathrm{a}$ & $\mathrm{a}$ & $a b$ & $\mathrm{a}$ & $\mathrm{ab}$ & $\mathrm{a}$ \\
\hline \multirow{2}{*}{ Ragi 3\% } & 2,278 & & 3,194 & & 2,111 & 2,667 & 3,056 & 2,556 \\
\hline & a & $2,889 \mathrm{ab}$ & $\mathrm{a}$ & $2,750 \mathrm{ab}$ & a & $\mathrm{a}$ & $a b$ & $\mathrm{a}$ \\
\hline \multirow{2}{*}{$\begin{array}{l}\text { Ragi } 1 \%+ \\
\text { gula }\end{array}$} & 3,278 & 3,167 & 3,528 & 3,444 & 2,917 & 3,111 & 3,306 & 2,972 \\
\hline & $\mathrm{b}$ & $\mathrm{b}$ & a & $\mathrm{b}$ & $\mathrm{b}$ & $\mathrm{a}$ & $\mathrm{ab}$ & $\mathrm{ab}$ \\
\hline \multirow{2}{*}{$\begin{array}{l}\text { Ragi } 2 \%+ \\
\text { gula }\end{array}$} & 2,861 & 3,139 & 3,278 & 3,139 & 2,861 & 3,028 & 3,389 & 3,194 \\
\hline & $a b$ & $\mathrm{~b}$ & $\mathrm{a}$ & $\mathrm{b}$ & b & $\mathrm{a}$ & $\mathrm{b}$ & $\mathrm{b}$ \\
\hline \multirow{2}{*}{$\begin{array}{l}\text { Ragi } 3 \%+ \\
\text { gula }\end{array}$} & 2,444 & 2,667 & 2,889 & 2,639 & 2,444 & 2,750 & 2,833 & 2,667 \\
\hline & $\mathrm{a}$ & $\mathrm{a}$ & $\mathrm{a}$ & $\mathrm{a}$ & $a b$ & $\mathrm{a}$ & $\mathrm{a}$ & $a b$ \\
\hline
\end{tabular}

Keterangan : a). Nilai KV Rasa hari ke $-3=14,33 \%$; KV Rasa hari ke $-5=11,85 \%$; KV Tekstur hari ke $-3=7,68 \%$ KV Tekstur hari ke - 5 =8,59\% ; KV Aroma hari ke - 3=11,29\% ; KV Aroma hari ke - 5=8,14\% ; KV Keseluruhan hari ke - 3 $=8,10 \%$; KV Keseluruhan hari ke $-5=10,62 \%$. b). Angka yang memiliki huruf yang sama menunjukan tidak adanya perbedaan nyata antar perlakuan menurut uji BNJ pada taraf $5 \%$. Sebaliknya apabila angka yang diikuti huruf yang berbeda akan menunjukan adanya perbedaan yang nyata antar perlakuan menurut uji BNJ pada taraf $5 \%$. c). Rs : Nilai Kesukaan rasa; Tkr : Nilai kesukaan Tekstur; Arm: Nilai kesukaan aroma ; Kslrn: Nilai kesukaan keseluruhan. 
mirip dengan biji gandum yang memberikan rasa manis dan bau khas tape.

Penambahan hari memiliki potensi kecenderungan menurunkan nilai kesukaan tekstur tape gandum. Menurut Hidayat, et al., (2006), fermentasi dapat merupakan sebagai perubahan gradual oleh enzim beberapa bakteri, khamir dan jamur. Semakin lama proses fermentasi, maka jumlah alkohol dan asam-asam organik yang dihasilkan akan semakin tinggi, sehingga teksturnya akan semakin lunak. Tekstur yang terlalu lunak ini kurang diminati oleh banyak panelis pada tape gandum. Menurut Amerine, et al., (1972), menyatakan semakin lama fermentasi maka asam-asam yang mudah menguap semakin banyak dengan semakin besarnya ragi tape dan lama fermentasi maka jumlah alkohol dan asam organik, karbondioksida akan semakin tinggi, dimana kita ketahui senyawa berbentuk cair dan gas, hal inilah yang menyebabkan tekstur tape semakin lunak.

Dosis ragi yang berbeda tidak memperlihatkan nilai kesukaan aroma yang berbeda pada hari ke-3. Menurut Setyohadi (2006), khamir Saccaromyces cereviceae menghasilkan enzim amilase yang merombak pati menjadi glukosa, glukosa tersebut diubah menjadi alkohol. Dalam tahapan hari ke-3, diduga mikroorganisme sedang merombak pati menjadi glukosa dan sedikit merombak gula menjadi alkohol. Sehingga pada hari ke tiga ini belum terlihat perbedaan aroma yang tajam antar masing-masing perlakuan. Sedangkan perbedaan kesukaan aroma pada hari ke-5 khususnya pada dosis ragi 3 persen menghasilkan kesukaan aroma paling rendah, hal ini disebabkan bakteri asam asetat seperti Acetobacter aceti dalam proses fermentasi bahan pangan mengoksidasi alkohol dan karbohidrat menjadi asam asetat. Dengan semakin besar persentase ragi tape, semakin banyak jumlah mikroorganisme perombak glukosa menjadi alkohol dan asam, yang didukung oleh penambahan gula maka semakin tinggi kandungan alkohol dan asam asetat dan senyawa lain yang membuat aroma tape gandum semakin tidak disukai (Buckle, et al., (1987).

Penambahan gula cenderung meningkatkan nilai kesukaan aroma kecuali pada dosis ragi 3 persen baik pada hari ke-3 maupun hari ke-5. Kapang Saccaromyces cereviceae dan Acetobacter aceti terdapat didalam ragi, khamir Saccaromyces cereviceae menghasilkan enzim amilase yang merombak pati menjadi glukosa, glukosa tersebut diubah menjadi alkohol oleh bakteri Acetobacter aceti alkohol dan karbohidrat dioksidasi menjadi asam asetat. Sehingga semakin tinggi kandungan gula maka akan semakin tinggi glukosa yang dirombak menjadi alkohol dan asam. Semakin tinggi jumlah gula, alkohol, asam asetat dan senyawa lainnya membuat aroma tape semakin tidak disukai pada tape gandum [Setyohadi (2006); Buckle, et al., (1987)].

Penambahan hari berpotensi cenderung menurunkan nilai kesukaan aroma tape gandum. Semakin lama proses fermentasi berlangsung, semakin banyak alkohol dan asam-asam organik yang dihasilkan, hal ini sesuai dengan literatur Amerine, et al., (1972) yang menyatakan semakin lama fermentasi, maka asam-asam mudah menguap yang dihasilkan semakin banyak. Semakin banyaknya asam-asam mudah menguap, alkohol dan senyawa lainya akan membuat aroma tape kurang disukai oleh panelis.

Perbedaan dosis ragi menghasilkan perbedaan kesukaan keseluruhan pada hari ke-3 yaitu pada penambahan gula. Kesukaan keseluruhan tertinggi diperoleh pada perlakuan dosis ragi 1 persen dengan penambahan gula. Semakin tinggi nilai kesukaan rasa, tekstur, dan aroma maka nilai kesukaan keseluruhan juga akan tinggi. Sedangkan perbedaan dosis ragi tidak memberikan perbedaan nyata pada nilai kesukaan keseluruhan hari ke-5. Hal ini juga dipengaruhi oleh nilai kesukaan rasa, tekstur, dan aroma pada hari yang sama yang juga tidak berbeda. Jika kesukaan keseluruhan pada hari ke-3 dan ke-5 dibandingkan, 
maka nilai kesukaan hari ke-3 memberikan potensi cenderung lebih disukai jika dibandingkan dengan hari ke-5. Panelis menyukai organoleptik tape gandum yang sedikit air, bertekstur seperti biji gandum, agak lunak, namun manis dan beraroma tape yang lembut.

\section{KESIMPULAN}

Berdasarkan hasil penelitian, analisis data dan pembahasan, maka dapat ditarik kesimpulan sebagai berikut:

(1) Dosis ragi 1 persen dapat memberikan kualitas tape biji gandum paling tinggi jika dibandingkan dengan dosis ragi 2 persen dan 3 persen, dan penambahan gula dapat meningkatkan kualitas tape biji gandum.

(2) Pemberian dosis ragi 1 persen dengan penambahan gula dengan inkubasi 3 hari memberikan kualitas tape paling tinggi dilihat dari segi kandungan gizi (air, protein, gula pereduksi dan alkohol) dan organoleptik (rasa, tekstur, aroma dan cita rasa keseluruhan).

\section{DAFTAR PUSTAKA}

Amerine. M. A. Berg and M. V. Croes. 1972. The Technology of Wine Making. The AVI Publishing Company, Wesport, Connecticut.

Anindita. 2007. Pengaruh Waktu Fermentasi dan Dosis Ragi Terhadap Kadar Alkohol Pada Fermentasi Ampas Umbi Ketela Pohon. Universitas Muhamadiyah Surakarta. JMS Vol. 6. No. 1, Oktober 2007.

Anonim $^{b}$, 2006. Isolasi Kapang dan khamir Ragi Tape. Institut Pertanian Bogor. http:// repository.ipb.ac.id/bitstream/handle/ 123456789/9097/bab\%204_2006dsr.pdf diakses 30Mei 2013.

Asngad, Aminah dan Suparti. 2009. LamaFermentasi dan Dosis Ragi yang Berbeda pada Fermentasi Gaplek Ketela Pohon (Manihot utilisima, Pohl) Varietas Mukibat Terhadap kadar Glukosa dan Bioetanol. Jurnal Penelitian Sains \& Teknologi, Vol. 10, No. 1, 2009: 1-9.
Buckle, K. A., R. A. Edwards, G. H. Fleet and M. Wotton, 1987. Ilmu Pangan. Pener-jemah H. Purnomo dan Adiono. UI-Press. Jakarta.

Desrosier, 1988. Teknologi Pegawetan Pangan. Penerjemah M. Muljohardjo. UI-Press. Jakarta.

Dewi, S. K. 2009. Rosella (Hibiscus sabdariffa L.) sebagai Pewarna Tape Ketan ditinjau dari Stabilitas Warna, pH, Kandungan Gula Pereduksi dan Alkohol. Universitas Kristen Satya Wacana. Salatiga.

Fardiaz, S. 1992, Mikrobiologi Pangan 1. Jakarta: PT. Gramedia Utama Pustaka.

Hidayat, Nur. 2006. Mikrobiologi Industri. Andi. Yogyakarta.

Murtini, E. S., Tri Susanto, dan Ratih Kusumawardani. 2005. Karakterisasi Sifat Fisik, Kimia, dan Fungsional Tepung Gandum Lokal Varietas Selayar, Nias dan Dewata. Jurnal Teknologi Pertanian, Vol. 6 No. 1 (April 2005) 57-65.

Rubatzky V.E. And M. Yamaguchi, 1988. Sayuran Dunia I Prinsip, Produksi dan Gizi. Penerjemah C.Herison. ITB-Press, Bandung.

Septiani, Y., Tjahjadi purwoko dan Artini pangastuti. 2004. Kadar Karbohidrat, Lemak, dan Protein pada Kecap dari Tempe. Jurnal Bioteknologi 1 (2): 48-53.

Setyohadi. 2006. Proses Mikrobiologi Pangan (Proses Pengolahan dan Kerusakan). USU-Press, Medan.

Simbolon, Karlina. 2008. Pengaruh Persentase Ragi dan Lama fermentasi Terhadap Mutu Tape Ubi Jalar. Departemen Teknologi Pertanian. Universitas Sumatera Utara. (htt://www.repository.usu.ac.id. diakses 1 Oktober 2011, 18:00).

Winarno, F. G dan S. Fardiaz. 1984. Biofermentasi dan Biosintesa Protein. Angkasa, Bandung.

$* * *$ 